\title{
Pengaruh Stres Kerja dan Persepsi Dukungan Organisasi Terhadap Produktivitas Karyawan yang di Mediasi oleh Self-Efficacy (Studi Pada Karyawan My Creative.Id Yogyakarta)
}

\author{
Ersary Purwaningtyas*, Epsilandri Septyarini \\ Fakultas Ekonomi, Universitas Sarjanawiyata Tamansiswa, Yogyakarta, 55165 \\ *Correspondence email : ersaryp@gmail.com
}

\begin{abstract}
Abstrak. Penelitian ini bertujuan untuk mengetahui pengaruh stres kerja dan persepsi dukungan organisasi terhadap produktivitas karyawan yang di mediasi oleh self-efficacy. Baik stres kerja, persepsi dukungan organisasi, self-efficacy menjadi faktor utama yang mempengaruhi produktivitas karyawan di sebuah perusahaan. Adapun tujuan dari penelitian ini sendiri adalah untuk menguji variabel stres kerja, persepsi dukungan organisasi, self-efficacy dan produktivitas karyawan yang bekerja di MY Creative.Id Yogyakarta, peneliti mengambil sampel dengan menerapkan metode non-probability dengan jumlah sampel jenuh. Kuesioner yang diolah berjumlah 50 orang karyawan. Hasil dalam penelitian ini menunjukkan bahwa : (1) Stres Kerja berpenagruh negatuf terhadap Produktivitas Karyawan, (2) Persepsi Dukungan Organisasi berpengaruh positif dan signifikan terhadap Produktivitas Karyawan, (3) Stres Kerja berpengaruh negatif terhadap Self-Efficacy, (4) Self-Efficacy berpengaruh positif dan signifikan terhadap Produktivitas Karyawan, (5) Persepsi Dukungan Organisasi berpengaruh positif dan signifikan terhadap Self-Efficacy, (6) Self-Efficacy tidak memediasi Stres Kerja terhadap Produktivitas Karyawan, (7) Self-Efficacy memediasi Persepsi Dukungan Organisasi terhadap Produktivitas Karyawan.
\end{abstract}

Kata Kunci : Persepsi Dukungan Organisasi, Produktivitas Karyawan, Self-Efficacy, Stres Kerja.

\begin{abstract}
This study was structured to determine the effect of job stress and perceived organizational support on employee productivity mediated by self-efficacy. Both job stress, perceived organizational support and self-efficacy are the main factors affecting employee productivity in a company. The purpose of this study itself is to test the variables of job stress, perceptions of organizational support, self-efficacy and productivity of employees who work at MY Creative.Id Yogyakarta, researchers took samples by applying a non-probability method with a saturated sample. The questionnaires that were processed were 50 employees. The results in this study indicate that: (1) Job Stress has a negative effect on employee productivity, (2) Perceptions of Organizational Support have a positive and significant effect on Employee Productivity, (3) Job Stress has a negative effect on Self-Efficacy, (4) Self-Efficacy. Efficacy has a positive and significant effect on Employee Productivity, (5) Perceptions of Organizational Support have a positive and significant effect on Self-Efficacy, (6) Self-Efficacy does not mediate Job Stress on Employee Productivity, (7) Self-Efficacy mediates Perceptions of Organizational Support on Productivity Employees.
\end{abstract}

Keywords: Perceptions of Organizational Support, Employee Productivity, Self-Efficacy, Job Stress.

\section{Pendahuluan}

Salah satu kinerja dari sebuah organisasi bisnis sering kali terletak dari kualitas sumber daya manusia yang dimiliki. Dengan demikian peran sumber daya manusia sangat penting di dalam organisasi. Maka sumber daya manusia mendapatkan perhatian intensif dibanding dengan faktor produksi lain. Produktivitas merupakan kemampuan karyawan dalam mencapai tugas teretentu sesuai standar, kelengkapan, biaya dan kecepatan sehingga pemanfaatan sumber daya manusia yang efisien dan efektif dalam sebuah organisasi sangat penting untuk meningkatkan efektivitas dan efisiensi secara keseluruhan (Andi Setyawan Suyitno, 2016). Produktivitas karyawan merupakan hal yang penting dalam perusahaan, jika karyawan bekerja secara produktif maka perusahaan dikatakan berhasil dan meraih tujuan. Jika produktivitas yang tinggi akan sangat menguntungkan bagi pimpinan maupun karyawan, terutama untuk kesejahteraannya.(Ni Kadek Ira Agustini, 2019) Kualitas sumber daya manusia dengan memperhatikan karyawan terutama segala kebutuhannya dalam pencapaian hasil atau output yang maksimal dan berkualitas. Seperti masalahmasalah yang muncul baik secara internal maupun eksternal karena hal ini akan mempengaruhi cara karyawan dalam bekerja. Masalah yang sangat berkaitan dalam mengurangi tekanan yang dialami karaywan, pemenuhan persepsi atau penilain rasa puas karyawan yang dapat penilaian rasa puas karyawan yang dapat menyebabkan tinggi rendahnya produktivitas karja karyawan di suatu. (Harrisma \& Witjaksono, 2013)

Stres kerja yang dialami oleh karyawan muncul karena adanya sikap karyawan dalam proses menyelesaikan pekerjaannya dikarenakan karyawan mengalami gangguan baik secara fisik maupun psikologi. Salah satu alasan mengapa stres kerja perlu dipahami adalah stres kerja tidak dapat bekerja secara optimal sehingga akan memberikan dampak negatif pada hasil kerjanya atau dengan kata lain karyawan tidak dapat mengoptimalkan hasil kerjanya. Karyawan juga perlu mendapatkan suatu dukungan dari organisasi. Sebab karyawan ingin merasa bahwa dirinya berkontribusi akan keberhasilan perusahaan. (I Gede Putro Wibowo, Gede Riana, 2015). Persepsi dukungan organisasi 
dapat didefinisikan sebagai persepsi karyawan mengenai sejauh mana organisasi menilai kontibusi mereka dan peduli pada kesejahteraan mereka (Rhoades \& Eisenberger,2002). Persepsi dukungan organisasi merupakan tingkatan dimana karyawan mempercayai bahwa organisasi menghargai kontribusi pegawai dan peduli terhadap kesejahteraan mereka sehingga menghasilkan hubungan timbal balik diantara keduanya. (Rahyuda, 2017). Salah satau penentu apakah individu akan dapat melaksanakan tugas aktivitas dan terus berusaha apabila menemui hambatan dalam mencapi tujuan tertentu, yaitu self-efficacy. (Asih \& Dewi, 2017).

Self-efficacy sangat diperlukan dalam mengembangkan kinerja karyawan karena dengan adanya self-efficacy dalam individu akan menimbulkan keyakinan akan kemampuan dirinya dalam menyelesaikan pekerjaan yang diberikan atasannya secara tepat waktu (Novianti, 2016). Self-efficacy merupakan keyakinan yang dimiiki tentang kemampuan atau ketidakampuan yang dimiliki untuk menunjukkan suatu perilaku atau sekumpulan perilaku tertentu. Sedangkan konsep self-efficacy berkaitan dengan sejauh mana individu mampu memiliki kemampuan, potensi serta kecenderungan yang ada pada dirinya untuk dipadukan mejadi tindakan tertentu untuk mengatasi situasi yang mungkin akan dihadapi di masa yang akan datang. (Kaseger, 2013)

Tujuan penelitian ini adalah pengaruh Stres Kerja dan Persepsi Dukungan Organisasi Terhadap Produktivitas Karyawan yang di Mediasi oleh Self-Efficacy.

\section{Metode}

Jenis penelitian menggunakan metode deskriptif kuantitatif yang dilakukan di MY Creative.Id yang terletak di Jl. Menteri Supeno, Pakel UH 5/449, RT 02/RW 01 Pandeyan, Kec. Umbulharjo, Kota Yogyakarta. Waktu penelitian pada tanggal 04-07 Februari 2021. Populasi pada penelitian ini menggunakan semua karyawan tetap maupun tidak tetap di MY Creative.Id. Teknik yang digunakan dalam pengambilan sample ini adalah dengan sampling jenuh dalam artian menggunakan semua populasi sebagai sampel. Pengumpulan data dalam penelitian ini diperoleh dengan cara membagikan kuesioner kepada responden. Pertanyaan yang diajukan pada penelitian ini adalah data primer, pengukuran pengaruh variabel menggunakan uji normalitas, tes hipotesis uji sobel, dll.

\section{Hasil}

Tabel 1.

Uji Validitas dan Reabilitas

\begin{tabular}{|c|c|c|c|c|c|c|c|}
\hline \multicolumn{2}{|c|}{ Stres Kerja } & \multicolumn{2}{|c|}{ Persepsi Dukungan Organisasi } & \multicolumn{2}{|c|}{ Self-Efficacy } & \multicolumn{2}{|c|}{ Produktivitas Karyawan } \\
\hline SK1 & 0,670 & PDO1 & 0,880 & SE1 & 0,830 & PK1 & 0,814 \\
\hline SK2 & 0,795 & PDO2 & 0,774 & SE2 & 0,811 & PK2 & 0,847 \\
\hline SK3 & 0,706 & PDO3 & 0,799 & SE3 & 0,717 & PK3 & 0,785 \\
\hline SK4 & 0,691 & PDO4 & 0,763 & SE4 & 0,835 & PK4 & 0,770 \\
\hline SK5 & 0,895 & PDO5 & 0,683 & SE5 & 0,800 & PK5 & 0,629 \\
\hline SK6 & 0,816 & & & SE6 & 0,777 & PK6 & 0,711 \\
\hline \multirow[t]{2}{*}{ SK7 } & 0,594 & & & SE7 & 0,746 & PK7 & 0,727 \\
\hline & & & & & & PK8 & 0,747 \\
\hline \multicolumn{8}{|c|}{ Croncbach's Alpha Based on Standarized Items } \\
\hline & 0,849 & & 0,836 & & 0,896 & & 0,890 \\
\hline
\end{tabular}

Sumber : Data Olahan

Hasil uji validitas pada tabel 1 menunjukkan nilai corrected item-total correlation $>r$ tabel $(0,2353)$ atau valid. Kemudian niali Croncbach's Alpha Stand pervariabel >0,60 yang berarti reliabel. Responden pada MY Creative.Id didominasi dengan jenis kelamin perempuan sebanyak 26 orang (52\%), rata-rata responden berusia 20-30 tahun sebanyak 44 responden (88\%), berdasarkan pendidikan terakhir paling banyak adalah SLTA/sederajat dengan jumlah responden sebanyak 27 orang (54\%) dan berdasarkan lama bekerja paling karyawan dengan lama kerja 1-2 tahun $(76 \%)$.

Tabel 2

Hasil Uji Normalitas (1)

\begin{tabular}{|l|l|r|}
\hline \multicolumn{2}{|l|}{} & \multicolumn{1}{c|}{ Unstandardized Residual } \\
\hline $\mathrm{N}$ & Mean & 50 \\
\hline \multirow{2}{*}{ Normal Parameters ${ }^{\mathrm{a}} \mathrm{b}$} & St. Deviation &, 0000000 \\
\hline \multirow{3}{*}{ Most Extreme Differences } & Absolute & 1,75574377 \\
\cline { 2 - 3 } & Positive &, 064 \\
\cline { 2 - 3 } & Negative &, 064 \\
Kolmogorov-Smirnov Z & &,- 045 \\
\hline Asymp. Sig. (2-tailed) &, 450 \\
\hline
\end{tabular}

Sumber : Data Olahan 
Ersary Purwaningtyas dan Epsilandri Septyarini, Pengaruh Stres Kerja dan Persepsi Dukungan Organisasi Terhadap Produktivitas Karyawan yang di Mediasi oleh Self-Efficacy (Studi Pada Karyawan My Creative.Id Yogyakarta)

Tabel 3

Hasil Uji Normalitas (2)

\begin{tabular}{|l|l|r|}
\hline \multicolumn{2}{|l|}{} & Unstandardized Residual \\
\hline N & 50 \\
\hline \multirow{2}{*}{ Normal Parameters } & Mean \\
& Std. Deviation &, 0000000 \\
Most Extreme Differences & Absolute & 2,29436754 \\
\cline { 2 - 3 } & Positive &, 097 \\
\hline Kolmogorov-Smirnov Z & Negative &, 062 \\
\hline Asymp. Sig. (2-tailed) &,- 097 \\
\hline
\end{tabular}

Sumber : Data Olahan

Tabel 4

Uji Heterokedatisitas (1)

\begin{tabular}{|c|c|c|c|c|c|c|}
\hline & \multirow{2}{*}{ Model } & \multicolumn{2}{|c|}{ Unstandardized Coefficients } & \multirow{2}{*}{$\frac{\text { Standardized Coefficients }}{\text { Beta }}$} & \multirow{2}{*}{$\mathrm{t}$} & \multirow{2}{*}{ Sig. } \\
\hline & & B & Std. Error & & & \\
\hline \multirow{3}{*}{1} & (Constant) & 3,923 & 1,426 & & 2,751 & ,008 \\
\hline & SK &, 018 &, 075 &, 058 &, 247 & ,806 \\
\hline & $\mathrm{PDO}$ &,- 141 & , 116 &,- 285 & $-1,217$ & 230 \\
\hline
\end{tabular}

Sumber : Data Olahan

Tabel 5

Uji Heterokedatisitas (2)

\begin{tabular}{|c|c|c|c|c|c|c|}
\hline & \multirow{2}{*}{ Model } & \multicolumn{2}{|c|}{ Unstandardized Coefficients } & \multirow{2}{*}{$\begin{array}{c}\text { Standardized Coefficients } \\
\text { Beta }\end{array}$} & \multirow{2}{*}{$\mathrm{t}$} & \multirow{2}{*}{ Sig. } \\
\hline & & \begin{tabular}{c|}
$\mathrm{B}$ \\
\end{tabular} & Std. Error & & & \\
\hline \multirow{4}{*}{1} & (Constant) & 4,650 & 1,686 & & 2,818 & ,008 \\
\hline & SK &,- 025 &, 087 &,- 069 &,- 286 & ,776 \\
\hline & PDO &,- 196 &, 158 &,- 351 & $-1,237$ & ,222 \\
\hline & SE & ,066 & , 106 &, 161 &, 627 &, 534 \\
\hline
\end{tabular}

Sumber : Data Olahan

Tabel 6

Hasil Uji Multikoliniearitas

\begin{tabular}{|l|l|r|r|}
\hline \multicolumn{2}{|c|}{ Model } & \multicolumn{2}{c|}{ Collinearity Statistics } \\
\cline { 3 - 5 } \multicolumn{2}{|c|}{} & Tolerance & \multicolumn{2}{c|}{ VIF } \\
\hline \multirow{2}{*}{1} & Stres Kerja & & \\
& Persepsi Dukungan Organisasi &, 652 & \\
& Self-Efficacy &, 496 & 1,535 \\
\cline { 2 - 5 } & & 527 & 2,014 \\
\hline
\end{tabular}

Sumber : Data Olahan

Tabel 7

Analisis Linier Berganda (I)

\begin{tabular}{|c|c|c|c|c|c|c|}
\hline & \multirow{2}{*}{ Model } & \multicolumn{2}{|c|}{ Unstandardized Coefficients } & \multirow{2}{*}{$\begin{array}{c}\text { Standardized Coefficients } \\
\text { Beta }\end{array}$} & \multirow{2}{*}{$\mathrm{t}$} & \multirow{2}{*}{ Sig. } \\
\hline & & $\mathrm{B}$ & Std. Error & & & \\
\hline \multirow{3}{*}{1} & (Constant) & 7,995 & 3,520 & & 2,271 & ,028 \\
\hline & SK & ,253 &, 151 & ,213 & 1,673 &, 101 \\
\hline & PDO & ,591 &, 138 & ,546 & 4,286 &, 000 \\
\hline
\end{tabular}

Sumber : Data Olahan

Tabel 8

Analisis Linier Berganda (2)

\begin{tabular}{|c|c|c|c|c|c|c|}
\hline & \multirow{2}{*}{ Model } & \multicolumn{2}{|c|}{ Unstandardized Coefficients } & \multirow[t]{2}{*}{ Standardized Coefficients } & \multirow{2}{*}{$\mathrm{t}$} & \multirow{2}{*}{ Sig. } \\
\hline & & $\mathrm{B}$ & Std. Error & & & \\
\hline \multirow{4}{*}{1} & (Constant) & 5,415 & 3,131 & & 1,106 & 275 \\
\hline & SK &, 029 & ,206 & ,018 & ,143 &, 887 \\
\hline & $\mathrm{PDO}$ & ,608 &, 215 & ,413 & 2,833 &, 007 \\
\hline & SE & ,492 & , 193 & ,361 & 2,555 & ,958 \\
\hline
\end{tabular}

Sumber : Data Olahan 

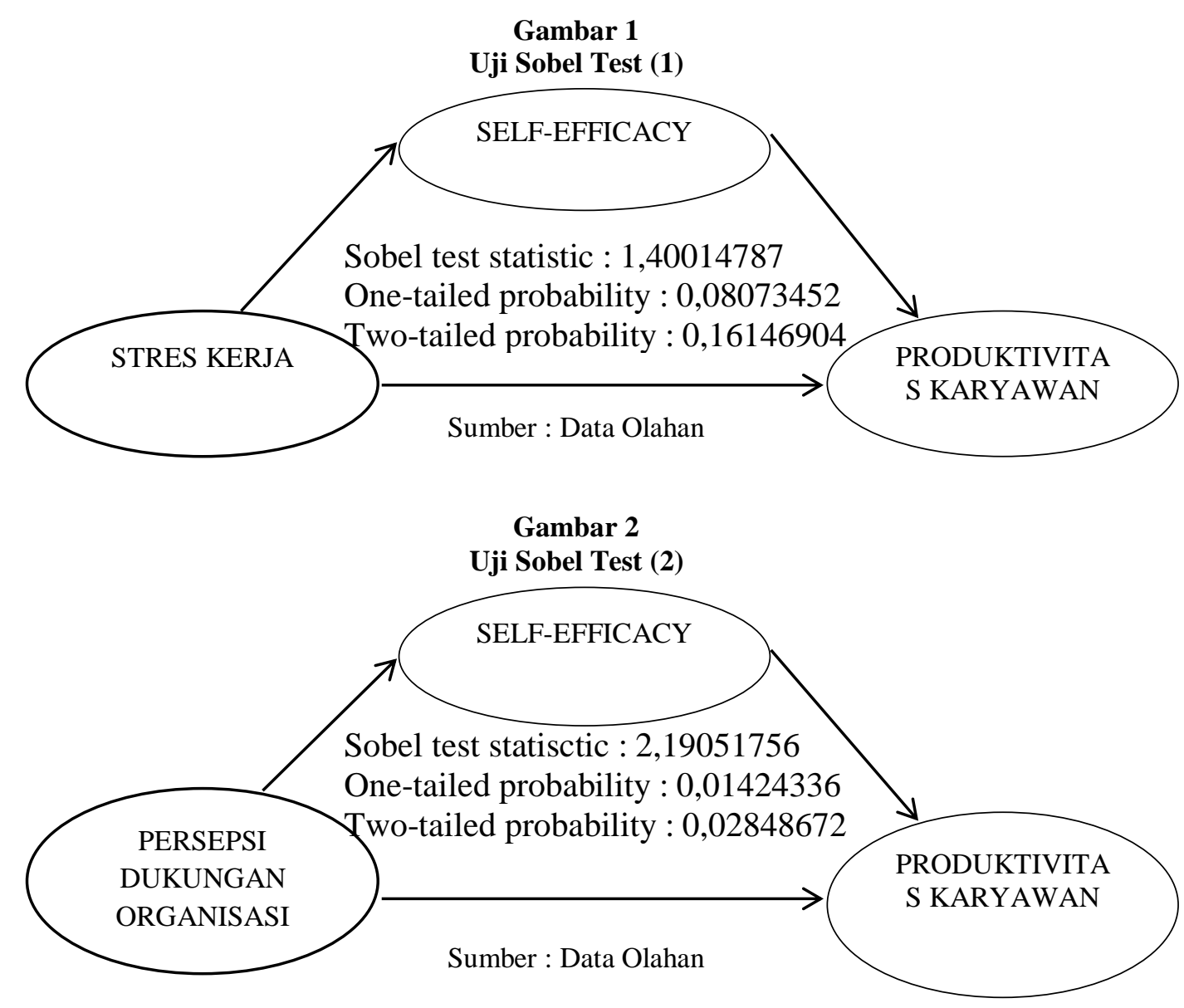

\section{Hasil pengujian Hipotesis menunjukkan bahwa :}

H1 : Stres Kerja berpengaruh Negatif terhadap Produktivitas Karyawan "Diterima". Dengan hasil nilai t htung 0,143 < 1,675 dan sig. sebesar 0,887>0,05. Hal ini disebabkan jika karyawan mengalami stres kerja maka berdampak pada produktivitas. Semakin tinggi stres kerja yang dialami oleh karyawan maka akan semakin rendah produktivitas karyawan.

H2 : Persepsi Dukungan Organisasi berpengaruh Positif dan Signifikan terhadap Produktivitas Karyawan "Diterima". Dengan hasil nilai $\mathrm{t}$ hitung $2,883>1,675$ dan sig. sebesar $0,007<0,05$. Hal ini dikarenakan jika karyawan mendapatkan dukungan dari organisasi maka akan berpengaruh pada produktivitas yang meningkat. Dengan artian semakin tinggi dukungan dari organisasi maka semakin tinggi pula produktivitas karyawan.

H3 : Stres Kerja berpengaruh Negatif terhadap Self-Efficacy "Diterima". Dengan hasil nilai t hitung 1,673 < 1,675 dan sig sebesar $0,101<0,05$. Hal ini disebabkan jika karyawan mengalami stres kerja yang berupa tekanan maka akan berdampak pada kepercayaan diri karyawan yang menurun yang akan menyebabkan karyawan menjadi terhambat untuk menyelesaikan pekerjaannya. Dalam artian semakin tinggi stres kerja maka akan semakin rendah self-efficacy karayawan tersebut.

H4 : Self-Efficacy berpengaruh Positif dan Signifikan terhadap Produktivitas Karyawan "Diterima". Dengan hasil nilai t hitung 2,555 $>1,675$ dan sig sebesar 0,014 <0,05. Hal ini dikarenakan, jika karyawan memiliki kepercayaan diri yang tinggi untuk melakukan pekerjaannya maka karyawan tersebut akan lebih cepat dan lebih mudah dalam menyelesaikan pekerjaan yang diberikan oleh organisasi dan akan berdampak pada produktivitas yang meningkat. Dengan artian semakin tinggi self-efficacy maka semakin tinggi pula produktivitas karaywan.

H5 : Persepsi Dukungan Organisasi berpengaruh Positif dan Signifikan terhadap Self-Efficacy "Diterima". Dengan hasil nilai t hitung 4,286 > 1,675 dan sig sebesar 0,000 < 0,05. Jika karyawan mendapatkan dukungan dari organisasi maka karaywan tersebut akan merasa ingin membalasnya dengan berkontribusi pada perusahaan, kontribusinya berupa karyawan menyelesaikan tugasnya dengan cepat dan efisien karenna memiliki tingkat kepercayaan diri yang tinggi dalam bekerja. Dengan artian semakin tinggi persepsi dukungan organisasi maka akan semakin tinggi pula selfefficacy pada karyawan.

H6 : Self-Efficacy Tidak Memediasi Stres Kerja terhadap Produktivitas Karyawan "Diterima". Hal ini dibuktikan dengan hasil one-tailed probability sebesar $0,080>0,05$. Karyawan yang mengalami stres kerja akan kehilangan keyakinan pada dirinya sendiri yang akan berdampak pada produktivitas yang menurun. Dengan artian semakin tinggi 
stres kerja yang dialami oleh karyawan maka akan semakin rendah self-efficacy pada karyawan yang akan menyebabkan produktivitas menurun.

H7 : Self-Efficacy Memediasi hubungan persepsi dukungan organisasi terhadap Produktivitas Karyawan "Diterima". Hal ini dibuktikan dengan hasil nilai one-tailed probabilty sebesar $0,014<0,05$. Karyawan yang mendapatkan dukungan organisasi akan memiliki perasaan kewajiban untuk membalasanya melalui dengan bekerja dengan efisien yang akan menyebabkan produktivitas akan meningkat. Dengan artian semakin tinggi persepsi dukungan organisasi maka self-efficacy pada karywan akan meningkat sehingga produktivitasnya semakin baik.

Tabel 9

Koefisien Determinasi (R2)

\begin{tabular}{|r|r|r|r|r|}
\hline \multicolumn{1}{|c|}{ Model } & R & \multicolumn{1}{|c|}{ R Square } & Adjusted R Square & \multicolumn{1}{c|}{ Std. Error of the Estimate } \\
\hline 1 &, $718^{\mathrm{a}}$ &, 515 &, 483 & 2,368 \\
\hline
\end{tabular}

Sumber : Data Olahan

Adjusted R Square sebesar 0,483. Dapat diartikan bahwa besarnya kontribusi antara stres kerja, persepsi dukungan organisasi, self-efficacy dan produktivitas karyawan sebesar $48,3 \%$ sedangkan $51,7 \%$ dipengaruhi oleh faktor lain yang tidak diteliti dalam penelitian ini.

\section{Simpulan}

Berdasarkan hasil penelitian yang dilakukan pada MY Creative.Id mengenai stres kerja dan persepsi dukungan organisasi terhadap produktivitas karyawan yang dimediasi oleh self-efficacy maka dapat ditarik kesimpulan:

a. Stres kerja berpengaruh negatif terhadap produktivitas karyawan. Hal ini ditunjukkan dengan hasil t-hitung sebesar $0,143<1,675$ dengan signifikansi $0,887>0,05$. H1 menyatakan bahwa produktivitas berpengaruh negatif terhadap produktivitas karyawan, diterima.

b. Persepsi dukungan organisasi berpengaruh positif dan signifikan terhadap produktivitas karyawan. Hal ini ditunjukkan dengan hasil t-hitung 2,883 > 1,675 dengan signifikansi $0,007<0,05$. H2 yang menyatakan persepsi dukungan organisasi berpengaruh positif terhadap produktivitas karyawan, diterima.

c. Stres kerja berpengaruh negatif terhadap self-efficacy. Hal ini ditunjukkan dengan nilai t-hitung sebesar 1,673< 1,675 dengan signifikansi $0,101>0,05$. H3 yang menyatakan stres kerja berpengaruh negatif terhadap selfefficacy, diterima.

d. Self-efficacy berpengaruh positif dan signifikan terhadap produktivitas karyawan. Hal ini ditunjukkan dengan nilai t-hitung sebesar 2,555 < 1,675 dengan signifikansi 0,014 $<0,05$. H4 yang menyatakan self-efficacy berpengaruh positif dan signifikan terhadap produktivitas karyawan, diterima.

e. Persepsi dukungan organisasi berpengaruh positif dan signifikan terhadap self-efficacy. Hal ini ditunjukkan dengan nilai t-hitung sebesar 4,286 > 1,675 dengan signifikansi $0,000<0,05$. H5 yang menyatakan persepsi dukungan organisasi berpengaruh positif dan signfikan terhadap self-efficacy, diterima.

f. Self-efficacy tidak memediasi stres kerja terhadap produktivitas karyawan. Hal ini ditunjukkan dengan hasil perhitungan sobel test sebesar 0,080>0,05. H6 yang menyatakan self-efficacy tidak memediasi stres kerja terhadap produktivitas karyawan, diterima.

g. Self-efficacy memediasi hubungan persepsi dukungan organisasi terhadap produktivitas karyawan. Hal ini ditunjukkan dengan hasil perhitungan sobel test sebesar 0,014 $<0,05$. H7 yang menyatakan self-efficacy memediasi persepsi dukungan organisasi terhadap produktivitas karyawan, diterima.

\section{Daftar Pustaka}

Andi Setyawan Suyitno, H. U. (2016). Among Makarti. Pengaruh Gaya Kepemimpinan Transformasional, Kompensasi Dan Budaya Organisasi Terhadap Produktivitas Kerja Karyawan (Studi Kasus Pada Perhimpunan BMT Indonesia Di Kabupaten Semarang), 57-79.

Asih, G. Y., \& Dewi, R. (2017). Jurnal Dinamika Sosial Budaya. Komitmen Karyawan Ditinjau Dari Self Efficacy Dan Persepsi Dukungan Organisasi, Di CV. Wahyu Jaya Semarang., 19(1), 35. https://doi.org/10.26623/jdsb.v19i1.684

Harrisma, O. W., \& Witjaksono, A. D. (2013). Jurnal Ilmu Manajemen. Pengaruh Stres Kerja Terhadap Produktivitas Kerja Melalui Kepuasan Kerja, 1(2), 650-662.

I Gede Putro Wibowo, Gede Riana, M. S. P. (2015). E-Jurnal Ekonomi dan Bisnis Universitas Udayana. Pengaruh Stres Kerja Terhadap Kepuasan Kerja Dan Komitmen Organisasional Karyawan, 04(02).

Kaseger, R. (2013). Jurnal EMBA. Pengembangan Karir Dan Self-Efficacy Terhadap Kinerja Karyawan Pada Matahari Departement Store Manado Twons Square, 1(4), 906-916. https://doi.org/10.35794/emba.v1i4.2827

Ni Kadek Ira Agustini, A. . S. K. D. (2019). E-Jurnal Manajemen. Pengaruh Kompensasi , Disiplin Kerja Dan 
Ersary Purwaningtyas dan Epsilandri Septyarini, Pengaruh Stres Kerja dan Persepsi Dukungan Organisasi Terhadap Produktivitas Karyawan yang di Mediasi oleh Self-Efficacy (Studi Pada Karyawan My Creative.Id Yogyakarta)

Motivasi Terhadap Produktivitas Karyawan, 8(1), 7191-7218.

Novianti, D. R. (2016). Jurnal Ilmu Manajemen. Pengaruh Self Efficacy Terhadap Kinerja Karyawan Dengan Motivasi Sebagai Variabel Intervening (Studi Pada Karyawan Divisi FInance Dan Divisi Human Resource PT. Coca-Cola DIistribution Indonesia, Surabaya), 4(3), 1-12.

Rahyuda, A. G. (2017). E-Jurnal Manajemen Unud. Pengaruh Perceived Organizational Support Terhadap Organizational Citizenship Behavior Dengan Variabel Kepuasan Kerja Sebagai Mediasi, 6(5), 2729-2755. 